\title{
Broiler Chicken PSE (Pale, Soft, Exudative) Meat and Water Release during Chicken Carcass Thawing and Brazilian Legislation
}

\author{
Talita Kato ${ }^{1}$, Claudia Freitas Barbosa ${ }^{2}$, Elza Iouko Ida ${ }^{2}$, Adriana Lourenço Soares ${ }^{2}$, \\ Massami Shimokomaki ${ }^{1,2,3}$ and Mayka Reghiany Pedrao ${ }^{1 *}$ \\ ${ }^{1}$ Universidade Tecnológica Federal do Paraná; Londrina - PR - Brasil. ${ }^{2}$ Programa de Pós-graduação em Ciência \\ de Alimentos; Universidade Estadual de Londrina; Londrina - PR - Brasil. ${ }^{3}$ Programa de Pós-graduação em \\ Ciência Animal; Universidade Estadual de Londrina; Londrina - PR - Brasil
}

\begin{abstract}
The objective of this work was to investigate the relationship between poultry PSE meat and water loss of frozen chicken carcass in two experiments. The first experiment was carried out in commercial abattoir. Poultry carcass were classified as PSE meat $(n=59)(p H \leq 5.8)$ and control samples $(n=55)(p H>5.8)$. Water absorption and drip test were performed according to the Brazilian legislation methodologies. The second experiment was carried out with commercial whole five brands frozen carcasses purchased from the local supermarkets $(n=30)$ and analyzed for $\mathrm{pH}$, water holding capacity (WHC) and drip test. PSE poultry meats absorbed $3.59 \%$ of water during the processing similar to the control samples; however, released 0.38\% more water during thawing of the carcasses. From these five brands evaluated, three presented drip values above 6.0\%. The highest drip value was showed by the brand sample that had $\mathrm{pH}$ and WHC values characteristics of PSE meat. It could be postulated that PSE meat phenomenon promoted more water release during thawing leading to a misinterpretation in relation to the Brazilian legislation for water carcass liberation during thawing.
\end{abstract}

Key words: drip loss, water absorption, water holding capacity

\section{INTRODUCTION}

The routine industrial plant processing of chicken meat is standardized in the slaughterhouses and consists essentially of a sequence of electrical stunning, bleeding, scalding, defeathering, evisceration, washing, carcass water cooling, deboning and refrigeration, or freezing storage (Northcutt 2001; Guarnieri et al. 2004). The water cooling of the carcass applied by the Brazilian companies in general consists of continuous passage in the tanks (chillers) that contain cold water and ice. Brazilian legislation requires the use of at least two pre-cooling tanks in sequence, with the maximum temperature as $16.0 \pm 5^{\circ} \mathrm{C}$ and $4.0 \pm$ $5^{\circ} \mathrm{C}$ for the first and second, respectively. The cooling of carcasses immediately after the slaughter and evisceration are requirements set in the Ordinance 210/98 - MAPA (Ministry of Agriculture, Livestock and Supply) requiring that the maximum temperature of the carcass at the second chiller exit should be $7.0 \pm 5^{\circ} \mathrm{C}$. For the carcass to be immediately frozen in sequence, this limit is $10.0 \pm 5^{\circ} \mathrm{C}$ (BRASIL 1998). Excessive loss of the water by poultry carcasses is the subject of constant complaints by the consumers (INMETRO 2010). In Brazil, water uptake by the carcasses is required to be controlled by the companies

*Author for correspondence: maykapedrao@utfpr.edu.br 
(according to the Brazilian Agriculture Department ordinance 210/98) (BRASIL 1998). However, frequently the water release during the thawing of carcasses in commercial trade with values above the limit established by the Brazilian law has been observed. Several companies have been penalized for presenting the carcasses with water content above the permitted by the law.

The excess water is not necessarily a result of fraudulent injection of water into the product, but the improper adjustment of technological variables that may influence the cooling process, such as final temperature of the chiller, initial weight of the chicken and air flow rate of bubbling pump (Carciofi and Laurindo 2007). The excessive release of water may be related to the phenomenon of PSE as the consequence of the stress brought about in particular by inadequately antemortem management (Bressan and Beraquet 2002; Guarnieri et al. 2004; Simões et al. 2009ab; Oba et al. 2009). It is well known that PSE conditions in broiler meat is the consequence from the myofibril proteins denaturation caused by rapid postmortem muscle glycolysis, which lowers the meat $\mathrm{pH}$ while the carcass is still warm (Olivo et al. 2001; Barbut et al. 2008). PSE is a meat color abnormalities occurring around the world in the USA, Woelfel et al. (2002) reported the PSE occurrence in 30-50\% of broiler meat and in Brazil, PSE was found in approximately $22 \%$ of broiler meat (Soares et al. 2003).

Water Holding Capacity (WHC) is the main characteristic examined in order to find meat proteins that are able to stabilize the meat emulsion affected by the PSE meat abnormalities. In fact, various methodologies have been developed by the meat group in order to decrease the occurrence of this abnormality such as the shower application at the farm just before the starting the journey (Simões et al. 2009ab; Langer et al. 2010), after the transport at the slaughterhouse (Guarnieri et al. 2004), use of blue light ambience immediately before their slaughter (Barbosa et al. 2011), addition of vitamin in the chicken diet (Olivo et al. 2001). All these techniques resulted in the lower rates of PSE meat occurrence. On the other hand, in order to improve the PSE meat functional properties, it was necessary to add some additives to produce a stable meat emulsion (Kissel et al. 2009).

In 2010, the Ministry of Agriculture published a methodology for the carcass water release measurement by thawing techniques. It is based on the chemical determination of moisture and protein ratio, while the former technique (the dripping test) quantified the loss of drip based on the difference between the weights of the fresh and thawed carcasses. The chicken cuts to be analyzed by this new method were breast, drumstick, thigh and the whole leg. However, whole carcasses are still being evaluated only by the dripping test, or drip test (BRASIL 1998). The maximum limit for the absorption and water loss (drip test) in fresh and frozen chicken carcasses allowed by the Ordinance 210/98 (MAPA) is 8.0 and $6.0 \%$, respectively. Although this provides slight improvement for the consumer protection, this legislation still fails to recognize that the eventual non-intentional maneuver can be brought about by the PSE phenomenon that affects the meat functional properties consequently giving rise to penalties and driving further responsibilities to the companies. The objective of this work, therefore, was to investigate the relationship between the poultry PSE meat and water loss during thawing of chicken carcass.

\section{MATERIALS AND METHODS}

\section{Drip Test on Whole Chicken Carcasses Water Loss Originating from A Commercial Slaughterhouse}

\section{Samples Preparation}

One hundred fourteen chicken whole carcasses samples were obtained from a commercial plant located in the south of Brazil (southwestern Parana state). The birds of the strains Cobb Fast and Avian 48, both genres were slaughtered at 42 days of age. The animals were slaughtered according to the standard industrial practice and essentially consisting of electrical stunning, bleeding, scalding, plucking, defeathering, evisceration, water-cooling the carcass. Before water-cooling, the carcasses were taken for $\mathrm{pH}$ analyses in order to be classified as PSE and control samples. The carcasses were selected for the analyses with intact skin, no broken wings, or drumstick. The evisceration of the birds was carried out by the removal of organs, lungs and elimination of excess fat in the abdominal region that could become detached during the cooling. The carcasses were collected in the slaughterhouse under the Federal Inspection Service (SIF) and were processed according to standards established by the Ordinance 210/98 (MAPA). 


\section{pH Measurements}

The $\mathrm{pH}$ was measured in duplicate by inserting the electrodes into the meat samples using a contact pH meter system (Testo, model 205), as reported in Olivo et al. (2001) after 12h post-mortem.

\section{Sample Classification}

The whole carcasses were classified to the $\mathrm{pH}$ value according to the classification proposed by Soares et al. (2002) where the carcass were classified as PSE at $\mathrm{pH} \leq 5.8$ and control at $\mathrm{pH}>5.8$. The $\mathrm{L}^{*}$ value was used with $\mathrm{pH}$ values in the characterization of PSE breast meat. However, the $\mathrm{L}^{*}$ value was not determined in this experiment because the carcass for the analysis of water absorption and drip test should have been with the intact skin not allowing the determination before water chiller and $\mathrm{L}^{*}$ value could not be determined after the drip test due to pre-cooking of breast fillet during the test. The classification was not affected because the correlationship between the $\mathrm{pH}$ and $\mathrm{L}^{*}$ had been established by several authors (Olivo et al. 2001; Woelfel et al. 2002; Soares et al. 2003; Guarnieri et al. 2004; Barbut et al. 2008).

\section{Measurement of Carcasses Water Absorption \\ The water absorption by the carcasses was measured according to the methodology recommended by the MAPA (BRASIL 1998). Basically, the carcasses were weighed (without the giblets, feet, head and neck), refrigerated in chiller for $36 \mathrm{~min}$, dripped for $10 \mathrm{~min}$ and subsequently weighed (final weight). The water absorption was expressed as the difference between the initial and final weight.}

\section{Freezing of Chicken Carcasses}

After the classification in the PSE, or control carcasses and also water absorption determination, these samples were packed in polyethylene bags, sealed and frozen in a freezing tunnel at $-30.0 \pm$ $5^{\circ} \mathrm{C}$ for $15 \mathrm{~h}$.

\section{Measurement of Water Loss Drip (Drip test)}

The samples were the same of the water absorption determination, which were identified as the PSE, or control carcasses samples. The evaluation of drip loss after thawing the carcasses was carried out according to the methodology recommended by Drip test, Ordinance 210/1998 MAPA (BRASIL 1998). The drip loss was expressed as [(initial weight - weight of packaging
- final carcass weight) / (initial weight - weight of the package)] x 100 .

\section{Statistical Analysis}

Statistical analysis was carried out using Statistic software, version 7.0. The Student $t$ test at 5\% level of significance was used to compare the means between the PSE and control meat in relation to the $\mathrm{pH}$, water absorption and drip test measurement. Pearson correlation coefficients were used for testing the correlations between the $\mathrm{pH}$, initial weight, water absorption and drip test on chicken carcasses.

\section{Drip Test on Whole Chicken Carcasses Water Loss Obtained From the Local Supermarkets}

\section{Samples Preparation}

Thirty frozen chicken carcasses of five brands were purchased from the supermarkets, six carcasses of each brand, in the region of Londrina/PR, transported to the laboratory and stored in a freezer at $-20^{\circ} \mathrm{C}$ until analysis.

\section{pH Measurement}

The $\mathrm{pH}$ was measured according to the methodology as described above.

\section{Water Holding Capacity (WHC) \\ WHC was determined based on the technique described by Hamm (1960). Basically, $2.0 \pm 0.10 \mathrm{~g}$ of samples were weighed, placed between two filter papers and then left under $10.0 \mathrm{~kg}$ weight for 5 min. The samples were weighed and WHC was determined by the exudated water weight through the following formula: $100-$ [(initial weight - final weight)/ (initial weight)].}

\section{Measurement of Water Loss Drip (Drip test)}

The methodology was according to the Ordinance $\mathrm{n}^{\circ} 210 / 98$ as mentioned above.

\section{Statistical Analysis}

Statistical analyses were performed using the Statistica software for Windows 7.0. The Tukey test at 5\% level of significance was used to compare the means of each physical-chemical analysis of different brands.

\section{RESULTS AND DISCUSSION}

\section{Drip Test on Whole Chicken Carcasses Water Loss Originating from A Commercial Slaughterhouse}


Table 1 shows the $\mathrm{pH}$, water absorption and drip test values for PSE and control carcasses. There was no significance difference between the PSE and control carcasses in percentage of water absorption, possibly due to the fact that at the time of measurement of water absorption, at the muscle level, the muscle biochemical transformation to meat and the rigor mortis was not completely installed. Thus, the proteins were probably not completely denatured and kept partially their functional properties by associating with water molecules, as observed also by Pearson's correlation coefficient between the values of $\mathrm{pH}$ and water absorption (Table 2), although the values were not significant $(-0.02 ; \mathrm{p} \leq 0.05)$.

Table 1 - Average values for $\mathrm{pH}$, water absorption and drip test on chicken carcasses classified as PSE and control meats.

\begin{tabular}{lccc}
$\begin{array}{c}\text { Carcasses } \\
\text { samples }\end{array}$ & pH & $\begin{array}{c}\text { Water } \\
\text { absorption (\%) }\end{array}$ & $\begin{array}{c}\text { Drip Test } \\
(\%)\end{array}$ \\
\hline $\begin{array}{l}\text { PSE } \\
(\mathrm{n}=59)\end{array}$ & $5.63^{\mathrm{b}} \pm 0.08$ & $3.57^{\mathrm{a}} \pm 0.76$ & $4.53^{\mathrm{a}} \pm 0.80$ \\
$\begin{array}{l}\text { Control } \\
(\mathrm{n}=55)\end{array}$ & $5.85^{\mathrm{a}} \pm 0.06$ & $3.56^{\mathrm{a}} \pm 1.06$ & $4.15^{\mathrm{b}} \pm 0.79$ \\
\hline $\begin{array}{l}\text { Means } \pm \text { SD followed by different letters in the same column } \\
\text { differ by Student test at 5\% significance level }(\mathrm{p} \leq 0.05) .\end{array}$
\end{tabular}

Table 2 - Pearson correlation coefficients among measurements of $\mathrm{pH}$, water absorption, drip test and carcass weight of the whole chicken carcasses.

\begin{tabular}{lcccc}
\hline & $\mathrm{pH}$ & $\begin{array}{c}\text { Water } \\
\text { absorption }(\%)\end{array}$ & $\begin{array}{c}\text { Drip test } \\
(\%)\end{array}$ & $\begin{array}{c}\text { Carcass } \\
\text { weight }(\mathrm{kg})\end{array}$ \\
\hline $\mathrm{pH}$ & - & -0.02 & $-0.30^{*}$ & 0.11 \\
$\begin{array}{l}\text { Water } \\
\begin{array}{l}\text { absorption } \\
(\%)\end{array}\end{array}$ & -0.02 & - & $0.61^{*}$ & $-0.19^{*}$ \\
$\begin{array}{l}\text { Drip test } \\
(\%)\end{array}$ & $-0.30^{*}$ & $0.61^{*}$ & - & $-0.25^{*}$ \\
$\begin{array}{l}\text { Carcass } \\
\text { weight }(\mathrm{kg})\end{array}$ & 0.11 & $-0.19^{*}$ & $-0.25^{*}$ & - \\
\hline
\end{tabular}

* Pearson correlation significant $(\mathrm{p} \leq 0.05)$.

The chicken PSE and control carcasses absorbed an average value of $3.57 \%$ of water. The carcasses water uptake was directly related to their weights. Smaller carcasses absorbed more water, because they had larger contact surface with water resulting in greater interaction between the pores of the carcass and water, with consequent increase in filling the pores with the chilled water (Carciofi and Laurindo 2007). This relationship between the carcass weight and water absorption was also confirmed by Pearson correlation (Table 2) that was negative and significant $(-0.19 ; \mathrm{p} \leq 0.05)$. Similar results have been reported by Essary and
Dawson (1965). The water temperature at the end of the chiller significantly influences the absorption of water due to the pore opening. According to Carciofi and Laurindo (2007) and Nascimento and Silva (2010), carcasses cooled to $1.0^{\circ} \mathrm{C}$ absorbed less water than the carcasses cooled to above $1.5^{\circ} \mathrm{C}$. The pores were responsible for about $25 \%$ of the absorbed water within the chiller, as they were open at the temperature in which the bird was at the end of the evisceration process (approximately $40.0^{\circ} \mathrm{C}$ ). When the chiller temperature was around $1.0^{\circ} \mathrm{C}$, the pores closed rapidly, reducing the tendency to be filled by water. Thus, the lower the temperature of the water in the chiller, less open pores would be found, consequently the lower would be the water absorption.

The loss of water by dripping in PSE carcasses was significantly higher than the control carcasses (Table 1). PSE meat had lower WHC due to its low $\mathrm{pH}$ and obviously by the consequence of the denaturation of myofibrilar and sarcoplasmic proteins (Olivo et al. 2001). There was a negative Pearson correlation between the $\mathrm{pH}$ and drip (Table 2), thus the decrease of $\mathrm{pH}$ was associated with the increase of water loss showing that water loss in the whole chicken carcass was associated with the protein denaturation due to the rapid glycolysis. A significant negative correlation was observed between the carcass weight and drip test (Table 2), suggesting that the lower the weight of carcass more water they would release after thawing. The carcass weight also was negatively correlated with water absorption; thus, lower the carcasses weight, higher was the absorbed water during their passage through the chiller. Although both, the chicken PSE and control carcasses absorbed similar amounts of water, PSE carcasses samples released more water measured by the dripping test due to low WHC in this abnormal meat.

\section{Drip Test on Whole Chicken Carcasses Water Loss Obtained From Local Supermarkets}

The results of $\mathrm{pH}$, WHC and drip test of chicken carcasses obtained from the local supermarkets are presented in Table 3. The brand A showed the lowest $\mathrm{pH}$ value (5.70) and also the lowest WHC $(62.98 \%)$. These values were typical for PSE breast meat as previously reported (Olivo et al. 2001; Soares et al. 2002; Guarnieri et al. 2004; Barbut et al. 2008; Wilhelm et al. 2010). pH values obtained by Soares et al. (2009) were 5.9 to 
6.0 for PSE meat and meat was not PSE. In a study published by Kissel et al. (2009), values were very similar being 5.77 to 5.93 for the PSE meat and no PSE meat.

Table 3 - Average values \pm standard deviation for $\mathrm{pH}$, water holding capacity (WHC) and Drip test of chicken carcasses obtained in local supermarkets.

\begin{tabular}{cccc}
\hline Brands & pH & WHC (\%) & Drip Test (\%) \\
\hline A & $5.70^{\mathrm{c}} \pm 0.10$ & $62.98^{\mathrm{b}} \pm 6.05$ & $8.32^{\mathrm{a}} \pm 3.04$ \\
B & $5.92^{\mathrm{ab}} \pm 0.07$ & $68.87^{\mathrm{ab}} \pm 2.32^{\mathrm{ab}}$ & $4.79^{\mathrm{bc}} \pm 0.90$ \\
C & $5.90^{\mathrm{b}} \pm 0.13$ & $66.99^{\mathrm{ab}} \pm 1.87$ & $3.75^{\mathrm{c}} \pm 0.88$ \\
D & $5.91^{\mathrm{b}} \pm 0.07$ & $69.26^{\mathrm{ab}} \pm 2.78$ & $6.69^{\mathrm{ab}} \pm 0.49$ \\
E & $6.07^{\mathrm{a}} \pm 0.07$ & $71.94^{\mathrm{ab}} \pm 5.13^{\mathrm{ab}}$ & $6.66^{\mathrm{ab}} \pm 1.59$ \\
\hline
\end{tabular}

Means \pm SD values followed by different letters in the same column differ by Tukey test at $5 \%$ significance level $(\mathrm{p} \leq 0.05)$.

Regarding the analysis of drip test, Brazilian legislation established the maximum of $6.0 \%$ (BRASIL 1998), and three commercial brands (A, $\mathrm{D}$ and E) (Table 3) had exceeded this limit. The brand A presented the highest value for drip test (8.32). This was probably due to the fact that this sample was characterized as PSE breast meat (based on the $\mathrm{pH}$ and WHC values). Although the drip test for the brands $\mathrm{D}$ and $\mathrm{E}$ showed an average above $6.0 \%$, they did not differ significantly from the brand $\mathrm{B}$ with an average value of 4.79 , thus below the $6.0 \%$ limit established by the legislation. Therefore, the PSE phenomenon led to higher release of water of frozen chicken carcass measured by the drip test due to the formation of protein denaturation.

\section{CONCLUSION}

The PSE meat promoted more water liberation during the thawing, leading to a misinterpretation of the Brazilian legislation in relation to the limit of the amount of water carcass liberation during broiler chicken carcass thawing.

\section{ACKNOWLEDGMENTS}

The financial support by Fundação Araucária/CNPq PRONEX (protocol $n^{\circ}$ 09277) is greatly acknowledged. CFB is under CAPES postgraduate scholarship. EII and MS are CNPq Research Fellows.

\section{REFERENCES}

Barbosa CF, Soares AL, Cymbalista C, Rossa A, Shimokomaki M, Ida EI. O uso da luz azul no controle do estresse durante o pré-abate dos frangos. Rev Nac Carne. 2011; 35: 22-27.

Barbut S, Sosnicki AA, Lonergan SM, Knapp T, Ciobanu DC, Gatcliffe LJ, Huff-Lonergan E, Wilson EW. Progress in reducing the pale, soft and exudative (PSE) problem in pork and poultry meat. Meat Sci. 2008; 79: 46-63.

BRASIL. Ministério da Agricultura, Pecuária e Abastecimento. Departamento de inspeção de produtos de origem animal. Secretaria de defesa agropecuária. Portaria $n^{\circ} 210$ de 26 de novembro de 1998. Regulamento técnico de inspeção tecnológica e higiênica sanitário de carnes de aves. Diário Oficial da União da República Federativa do Brasil, Brasília, 25 nov. 1998.

BRASIL. Ministério da Agricultura, Pecuária e Abastecimento. Instrução Normativa $n^{\circ} 32$ de 3 de dezembro de 2010. Estabelece os parâmetros para avaliação do Teor de Água Contida nos Cortes de Frangos, resfriados e congelados, na forma dos Anexos I, II, III, IV e V. Diário Oficial da República Federativa do Brasil, Brasília, 7 de dez. 2010.

Bressan MC, Beraquet NJ. Efeito de fatores pré-abate sobre a qualidade da carne de peito de frango. Ciênc Agrotec. 2002; 26(5): 1049-1059.

Carciofi BAM, Laurindo JB. Water uptake by poultry carcasses during cooling by water immersion. Chem Eng Process. 2007; 46(5): 444-450.

Essary EO, Dawson LE. Quality of fryer carcass as related to protein and fat levels in the diet. 1. Fat deposition and moisture pick-up during chilling. Poult Sci. 1965; 44(01): 7-15.

Guarnieri PD, Olivo R, Soares AL, Ida EI, Lara JAF, Shimokomaki M. Preslaughter handling with water shower spray inhibits PSE (Pale, soft, exudative) broiler breast meat in a commercial plant. Biochemical and ultrastructural observations. J Food Biochem. 2004; 28(4): 269-277.

Hamm R. Biochemistry of meat hydration. Advan Food Res. 1960; 10: 355-362.

INMETRO - INSTITUTO NACIONAL DE METROLOGIA. Programa de Análise de produtos: Relatório provisório da análise em frangos congelados peito com osso com pele e peito sem osso sem pele. Rio de Janeiro, p.1-13, 2010.

Kissel C, Soares AL, Rossa A, Shimokomaki M. Functional properties of PSE (Pale, Soft, Exudative) broiler meat in the production of mortadella. Braz Arch Biol Technol. 2009; 52: 213-217. 
Langer R, Simões GS, Soares AL, Oba A, Rossa A, Shimokomaki M, Ida EI. Broiler transportation conditions in a Brazilian commercial line and the occurrence of breast PSE (Pale, Soft, Exudative) meat and DFD-like (Dark,Firm, Dry) meat. Braz Arch Biol Technol. 2010; 53(5): 1161-1167.

Nascimento JC, Silva A. Análise estatística do processo de absorção de água pelas carcaças de frango em chiller industrial. In: EMEPRO 2010 - VI Encontro mineiro de engenharia de Produção: Proceedings: Contributed oral presentation; 2010 abr/maio; Coronel Fabriciano, Minas Gerais; 2010.

Northcutt JK. Preslaughter factors affecting poultry meat quality. In: SAMS, A.R. Poultry meat processing. Boca Raton: CRA Press, 2001, p.5-18.

Oba A, Almeida M, Pinheiro JW, Ida EI, Marchi DF, Soares AL, Shimokomaki M. The effect of management of transport and lairage conditions on broiler chicken breast meat quality and DOA (Death on Arrival). Braz Arch Biol Technol. 2009; 52: 205211.

Olivo R, Soares AL, Ida EI, Shimokomaki M. Dietary vitamin $\mathrm{E}$ inhibits poultry PSE and improves meat function proprieties. J Food Biochem. 2001; 25(4): 271-283.

Simões GS, Oba A, Matsuo T, Rossa A, Shimokomaki M, Ida EI. Vehicle thermal microclimate evaluation during Brazilian summer broiler transport and the occurrence of PSE (Pale, Soft, Exudative) meat. Braz Arch Biol Technol. 2009a; 52: 195-204.

Simões GS, Rossa A, Oba A, Matsuo T, Shimokomaki M, Ida EI. Influência do transporte em frangos PSE e a-DFD. Rev Nac Carne. 2009b; 23: 20-30.
Soares AL, Lara JAF, Ida EI, Guarnieri PD, Olivo R, Shimokomaki M. Variation in the colour of Brazilian broiler breast fillet. Proceedings international. Congress of Meat Science Technology, Roma, v.48, n.2, p. 540-541, 2002.

Soares AL, Lara JAF, Ida EI, Guarnieri PD, Olivo R, Shimokomaki M. Influence of preslaughter handling practices on broiler meat color in a commercial plant. In: 2003 IFT Annual Meeting and Food Expo, 2003, Chicago. 2003 IFT Annual Meeting Book of Abstracts, 2003. p. 201.

Soares AL, Marchi DF, Matsushita M, Guarnieri PD, Droval AA, Ida EI et al. Lipid oxidation and fatty acid profile related to broiler breast meat color abnormalities. Braz Arch Biol Technol. 2009; 52: 1513-1518.

Wilhelm AE, Magaghini MB, Hernández-Blazquez FJ, Ida EI, Shimokomaki M. Protease activity and the ultrastructure of broiler chicken PSE (pale, soft, exudative) meat. Food Chem. 2010; 119: 1201-1204.

Woelfel RL, Owens CM, Hirschler EM, MartinezDawson R, Sams AR. The characterization and incidence of pale, soft, and exudative broiler meat in a commercial processing plant. Poult Sci. 2002; 81: $579-584$. 